\title{
Clinical Features and Treatment of Pediatric Somatotropinoma: Case Study of an Aggressive Tumor due to a New AIP Mutation and Extensive Literature Review
}

\author{
Claire Personnier $^{\mathrm{a}, \mathrm{b}} \quad$ Laure Cazabat $^{\mathrm{e}}$ Jérôme Bertherat ${ }^{\mathrm{e}, \mathrm{k}} \quad$ Stephan Gaillard $^{\mathrm{f}, \mathrm{h}}$ \\ Jean-Claude Souberbielle ${ }^{c}$ Jean Louis Habrand ${ }^{i}$ Christelle Dufour ${ }^{j}$ \\ Eric Clauser ${ }^{g, k}$ Christian SainteRose ${ }^{d}$ Michel Polak $^{a, b, k}$ \\ a Paediatric Endocrinology and Gynaecology Unit, bentre des Maladies Endocriniennes Rares de la Croissance, \\ 'Functional Explorations Unit and dPaediatric Neurosurgery Unit, Assistance Publique, Hôpitaux de Paris, \\ Hôpital Necker-Enfants Malades, ${ }^{\mathrm{e} I n s t i t u t ~ C o c h i n ~ a n d ~ f ~ N e u r o s u r g e r y ~ U n i t, ~ I N S E R M ~ U 1016, ~ C R N R S ~ 8104, ~}$ \\ ${ }^{g}$ Oncogenetic Unit, Assistance Publique, Hôpitaux de Paris, Hôpital Cochin, h' Neurosurgery Unit, Hôpital Foch, \\ 'Paediatric Radiotherapy Unit, and 'Paediatric Oncology Unit, Institut Gustave Roussy, and kUniversité Paris \\ Descartes, Paris, France
}

\section{Key Words}

AIP $\cdot$ Mutation $\cdot$ Pediatric somatotropinoma $\cdot$ Pegvisomant

\begin{abstract}
Context: Pediatric somatotropinoma is uncommon but usually more aggressive than in adults, creating therapeutic challenges. No treatment guidelines are available. Objectives: To describe the features of pediatric somatotropinomas and to assess therapeutic strategies based on an extensive literature review. Design: We describe a pediatric case of aggressive somatotropinoma with an AIP mutation. We identified 137 pediatric somatotropinoma cases published between 1981 and 2010, and found 41 cases with AIP mutations in the main review. Results: We found a slight male preponderance (59\%). Median age was 9 years at symptom onset and 14 years at diagnosis. Macroadenomas accounted for $90 \%$ of the tumors; $2 / 3$ of the children had hyperprolactinemia at diagnosis. The first-line treatment was pharmacotherapy in one third and surgery in $2 / 3$ of the patients. Pegvisomant was used in 7 patients and produced significant improvement in 4 . The male preponderance was higher in the
\end{abstract}

\section{KARGER}

Fax +4161306 1234

E-Mail karger@karger.ch

www.karger.com
(C) 2011 S. Karger AG, Basel

$1663-2818 / 11 / 0756-0392 \$ 38.00 / 0$

Accessible online at:

www.karger.com/hrp subgroup with AIP mutations. Mutations leading to severe protein abnormalities were more common than reported in adults. Conclusion: Higher invasiveness and tumor volume in pediatric somatotropinomas require complex treatment combinations, which produce variable results. Pegvisomant is an effective drug whose usefulness in children remains to be determined. Genetic screening, particularly for AIP mutations, should be performed routinely.

Copyright $\odot 2011$ S. Karger AG, Basel

\section{Introduction}

Pituitary adenomas are uncommon in children, in whom they make up less than $3 \%$ of all supratentorial tumors [1]. Somatotropinomas account for $5-15 \%$ of pituitary adenomas, being less common than prolactinomas and corticotropinomas $[1,2]$. The clinical presentation of growth hormone $(\mathrm{GH})$ oversecretion by a somatotropinoma depends on the epiphyseal plate status. In patients with open epiphyseal plates, the excess $\mathrm{GH}$ accelerates growth, leading to gigantism. As the time of epiphyseal

Michel Polak, MD, PhD

Paediatric Endocrinology and Gynaecology, Hôpital Necker-Enfants Malades 149, rue de Sèvres

FR-75015 Paris (France)

Tel. +33 14449 4802, E-Mail michel.polak@nck.aphp.fr 


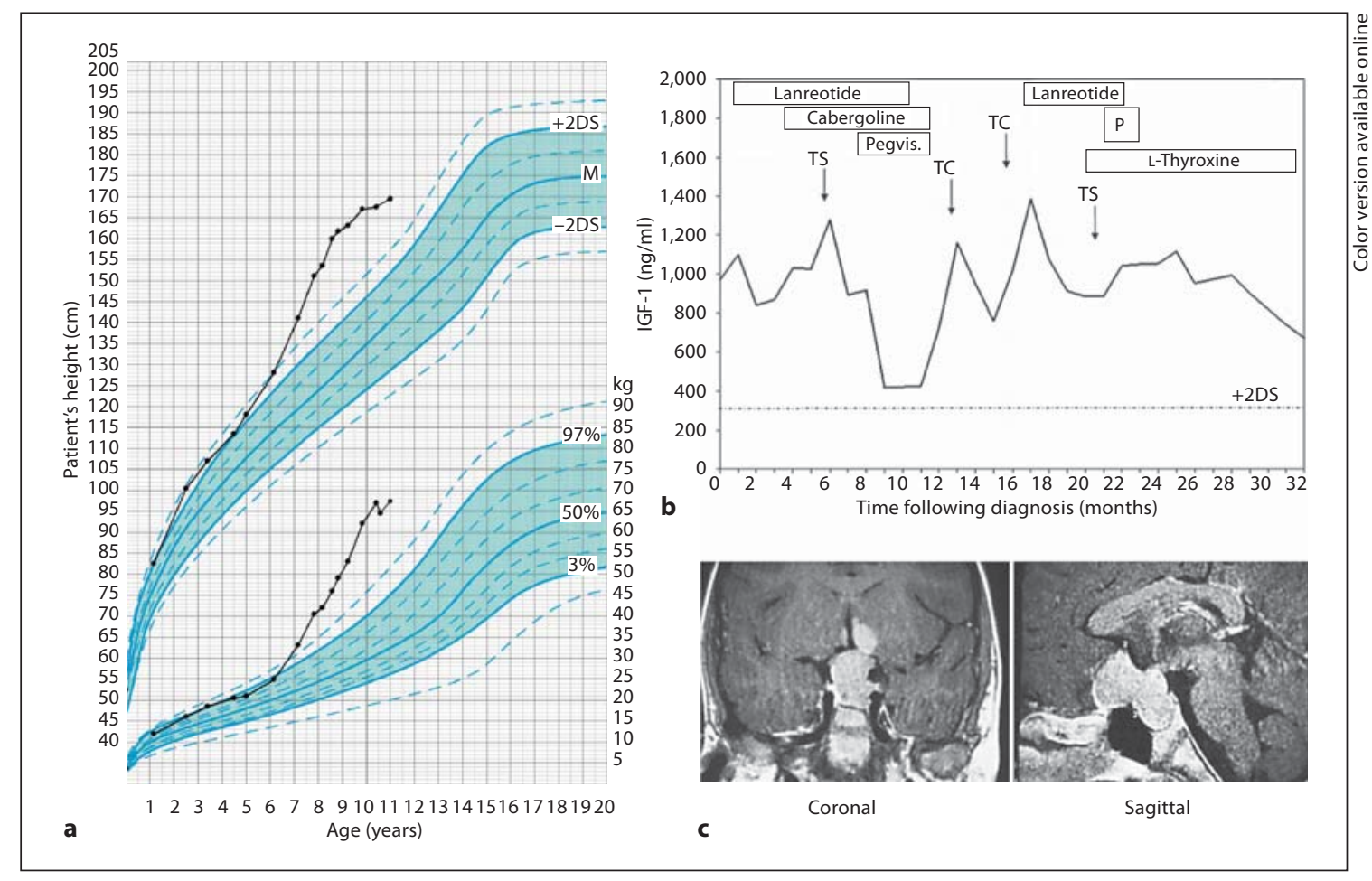

Fig. 1. a Growth curves of the patient. $\mathbf{b}$ Plasma IGF-1 concentrations according to the treatments used. TS = Transphenoidal surgery; $\mathrm{TC}=$ transcranial surgery; $\mathrm{P}=$ proton therapy; Pegvis = pegvisomant. $\mathbf{c}$ Pre-operative MRI ( $T_{1}$-weighted images).

fusion approaches, the clinical features become more similar to those seen in adults $[1,2]$. Somatotropinomas in children are often larger than in adults [6], and their behavior is invasive in $30-60 \%$ of cases $[7,8]$. These characteristics raise treatment challenges, particularly as no therapeutic guidelines are available for children. Highly variable results have been reported with conventional treatments (surgical excision, pharmacotherapy, and radiotherapy). The newly introduced GH receptor antagonist pegvisomant decreases IGF-1 production and controls the symptoms in adults [9-11], but has not been adequately evaluated in children.

The objectives of this paper were to describe the epidemiology, features, and treatment of pediatric somatotropinoma based on an extensive literature review and on a case report. We compared the pediatric management with recommendations issued for adults. This work has also given us the opportunity to review the published pediatric cases with mutations in the aryl hydrocarbon receptor interacting protein $(A I P)$ gene known to predispose carriers to somatotropinoma, particularly in younger patients.

\section{Material and Methods}

\section{Case Report}

An 8-year-old boy presented at the Necker-Enfants Malades Hospital with a 2-year history of growth acceleration (fig. 1). He was born at full term with a weight of $3,710 \mathrm{~g}$, a length of $52.5 \mathrm{~cm}$, and a head circumference of $35 \mathrm{~cm}$. His growth was normal until 5 years of age when he started gaining both weight and height at an accelerated rate. Parental heights were $187 \mathrm{~cm}$ (father) and 168 $\mathrm{cm}$ (mother). On physical examination, he was prepubertal. His height was $151.7 \mathrm{~cm}$ (over +4 SDs) and his weight was $40 \mathrm{~kg} \mathrm{(+3}$ SDs). He displayed mild prognathism, macroglossia, and right ocular ptosis. He also complained of knee pain, profuse sweating, and snoring. He reported no headaches, visual disturbances, polyuria, or polydipsia.

Hormone assays showed increased levels of IGF-1 (968 ng/ml; normal $=72-336 \mathrm{ng} / \mathrm{ml}$ ) and basal GH (34-45 ng/ml). A glucose tolerance test revealed normal carbohydrate tolerance, but no suppression of GH concentrations. The IGFBP-3 level was very high $[9.03 \mu \mathrm{g} / \mathrm{ml}$; normal $=0.3-4.7]$. Levels were normal for prolactin, thyroid hormones, and adrenal hormones. His bone age matched his chronological age. Cerebral MRI showed a large holosellar macroadenoma ( $30 \mathrm{~mm}$ in diameter) extending to the suprasellar area. The visual field was normal.

Treatment with lanreotide (60 mg monthly) had no effect on the IGF-1 levels (850-1,000 ng/ml), GH levels (>50 ng/ml), or tu-

Horm Res Paediatr 2011;75:392-402 
mor size (no change). Cabergoline ( $0.5 \mathrm{mg}$ weekly) was added 3 months later but was not effective [IGF-1 850-1,300 ng/ml, $\mathrm{GH}>50 \mathrm{ng} / \mathrm{ml}$. After 5 months of pharmacological treatment, partial tumor excision was performed via the transsphenoidal approach. Immunohistochemical staining confirmed the diagnosis of GH-secreting adenoma and showed a high proliferative index (12\% of MIB-1-positive cells). Two months after surgery, lanreotide and cabergoline were discontinued. Pegvisomant (10 mg daily) was given for 4 months but then stopped because of continued tumor growth with the development of visual disturbances. These visual symptoms prompted emergency transcranial surgery, which allowed only partial tumor excision. Another transcranial surgical procedure 4 months later also failed to ensure complete tumor excision. Lanreotide (90 mg monthly) was given for 7 months, then discontinued because of gastrointestinal side effects. Transsphenoidal surgery allowed nearly complete tumor resection, with only small intrasellar and suprasellar remnants. Thyrotropin insufficiency developed after the last surgery, requiring hormone replacement therapy. Proton therapy was given at a total dose of $52.2 \mathrm{~Gy}$. At his last visit 15 months after proton therapy, he was 11 years old, his IGF-1 level was $452 \mathrm{ng} / \mathrm{ml}$ (nor$\mathrm{mal}=72-336 \mathrm{ng} / \mathrm{ml}$ ), his $\mathrm{GH}$ level was $0.7 \mathrm{ng} / \mathrm{ml}$, and his growth velocity had decreased. MRI showed a decrease in remnant size $(13 \times 12 \mathrm{~mm})$.

Genetic analysis of blood and tumor tissue identified a novel heterozygous c. $2 \mathrm{~T}>\mathrm{C}$ mutation in exon 1 of the $A I P$ gene in peripheral blood cells from the patient and his mother and brother, as well as loss of the wild-type AIP allele in the patient's tumor tissue. This is the first reported mutation of the initiation codon ATG, which is responsible for mRNA translation in the AIP gene. tion.

Informed consent was obtained from the parents for publica-

\section{Literature Review}

We searched the Medline database using the key words 'gigantism', 'acromegaly', 'children', 'adolescent', 'somatotropinoma', 'somatotroph adenoma', and 'GH-secreting adenoma'. We identified 137 cases of pediatric somatotropinoma diagnosed between 0 and 18 years of age for which the available data (demographic and clinical features, laboratory data, imaging study findings, immunohistochemistry findings, and treatment) were sufficient for analysis. These 137 cases were reported in 45 articles published between 1981 and 2010 (see 'Appendix'). Follow-up ranged from several months to 30 years.

Furthermore, it was from this review that we found the 41 pediatric cases of AIP mutations reported between 2006 and 2010.

Statistical Analysis

The data were analyzed using the $\chi^{2}$ and Wilcoxon tests. $\mathrm{p}$ values $<0.05$ were considered significant.

\section{Results}

Table 1 shows the main features of the 137 previous cases and our case. Symptoms of GH oversecretion predominated, followed by symptoms of compression. Two asymptomatic children were diagnosed by family screen- ing. Macroadenomas accounted for almost $90 \%$ of the tumors, and immunohistochemistry showed equal proportions of GH-secreting and GH/PRL-secreting adenomas.

Table 2 shows the treatments and outcomes in 68 patients for whom relevant data were available (67 previously published cases and our case). The first-line treatment was surgical in two thirds of patients and pharmacological in the remaining third. Repeated surgical procedures were required in one fifth of patients. Among children given first-line pharmacotherapy, $80 \%$ received somatostatin receptor ligands. Radiotherapy was used in one third of patients. The GH receptor antagonist pegvisomant was used in 7 children, as the third- or fourth-line treatment. At last follow-up, disease control was achieved in almost $70 \%$ of children. Among them, $32 \%$ were still being treated and $37 \%$ had stopped treatment. GH oversecretion persisted in $26 \%$ of patients, and the tumor recurred in $4 \%$ of patients.

Figure 2 reports the 41 published pediatric cases with AIP mutations. The analysis of the cohort found a male preponderance $(70 \%)$ and a high proportion of macroadenomas (85\%).

\section{Discussion}

We analyzed 138 cases of pediatric somatotropinoma from an extensive literature review and 1 personal case. Despite the limitations of our work related to the variations in available data, management, and follow-up duration, our results provide a useful overall picture of pediatric somatotropinoma.

Males predominated slightly (59\%). Median age was 9 years $(0.2-17)$ at symptom onset and 14 years $(0.8-18)$ at diagnosis, indicating considerable diagnostic delay, in keeping with earlier data [12]. Accelerated growth, which was a feature in $66 \%$ of patients, should alert professionals to the possibility of somatotropinoma. However, the long time to diagnosis indicates inadequate awareness of this condition among physicians and families. Acromegalic features were present in as many as $37 \%$ of patients, despite the young age. Variable pubertal disorders occurred in $24 \%$ of patients. The available data did not allow us to determine whether amenorrhea and hypogonadism were related to gonadotropic insufficiency or to hyperprolactinemia. Previous publications did not provide explanations to the occurrence of precociouspubertyor adrenarche.

Pediatric somatotropinomas are usually large [6], a feature that explains the $23 \%$ rate of compression symp- 
Table 1. Main features in 138 pediatric patients with somatotropinoma

\begin{tabular}{|c|c|c|c|c|c|c|}
\hline & \multicolumn{2}{|c|}{ Total } & \multicolumn{2}{|c|}{ Males } & \multicolumn{2}{|c|}{ Females } \\
\hline & $\mathrm{n}$ & range or $\%$ & $\mathrm{n}$ & range or $\%$ & $\mathrm{n}$ & range or $\%$ \\
\hline Number & 138 & & 82 & 59.4 & 56 & 40.6 \\
\hline Median age at symptom onset, years & 9 & $0.2-17$ & 9 & $0.5-17$ & 7.2 & $0.2-17$ \\
\hline Median age at diagnosis, years & 14 & $0.8-18$ & 15 & $2.2-18$ & 14 & $0.8-18$ \\
\hline Number with data & 117 & & 69 & & 48 & \\
\hline Gigantism & 77 & 65.8 & 44 & 63.8 & 33 & 68.8 \\
\hline Acromegalic features & 43 & 36.8 & 23 & 33.3 & 20 & 41.7 \\
\hline \multicolumn{7}{|l|}{ Amenorrhea } \\
\hline Primary & 8 & 6.8 & n.a. & n.a. & 8 & 16.7 \\
\hline Secondary & 5 & 4.3 & n.a. & n.a. & 5 & 10.4 \\
\hline Number & 27 & 23.1 & 20 & 29.0 & 7 & 14.6 \\
\hline Headache & 18 & 15.4 & 14 & 20.3 & 4 & 8.3 \\
\hline Visual disturbances & 18 & 15.4 & 12 & 17.4 & 6 & 12.5 \\
\hline Asymptomatic & 2 & 1.7 & 1 & 1.4 & 1 & 2.1 \\
\hline \multicolumn{7}{|l|}{ Hormone profile } \\
\hline Number with data & 29 & & 15 & & 14 & \\
\hline Median level, $\mathrm{ng} / \mathrm{ml}$ & 855 & $460-1,963$ & 778 & $460-1,963$ & 937 & $495-1,540$ \\
\hline \multicolumn{7}{|l|}{ GH } \\
\hline Number with data & 69 & & 37 & & 32 & \\
\hline Median level, ng/ml & 51 & $4.6-730$ & 47 & $4.6-730$ & 74 & $9.7-475$ \\
\hline \multicolumn{7}{|l|}{ Tumor size } \\
\hline Number with data & 111 & & 66 & & 45 & \\
\hline Macroadenoma & 98 & 88.3 & 57 & 86.4 & 41 & 91.1 \\
\hline Microadenoma & 13 & 11.7 & 9 & 13.6 & 4 & 8.9 \\
\hline \multicolumn{7}{|l|}{ Immunostaining } \\
\hline Number with data & 106 & & 62 & & 44 & \\
\hline GH alone & 55 & 51.9 & 35 & 56.5 & 20 & 45.5 \\
\hline $\mathrm{GH}+$ prolactin & 51 & 48.1 & 27 & 43.5 & 24 & 54.5 \\
\hline
\end{tabular}

n.a. = Not applicable 
Table 2. Therapeutic strategy and outcomes in 68 patients

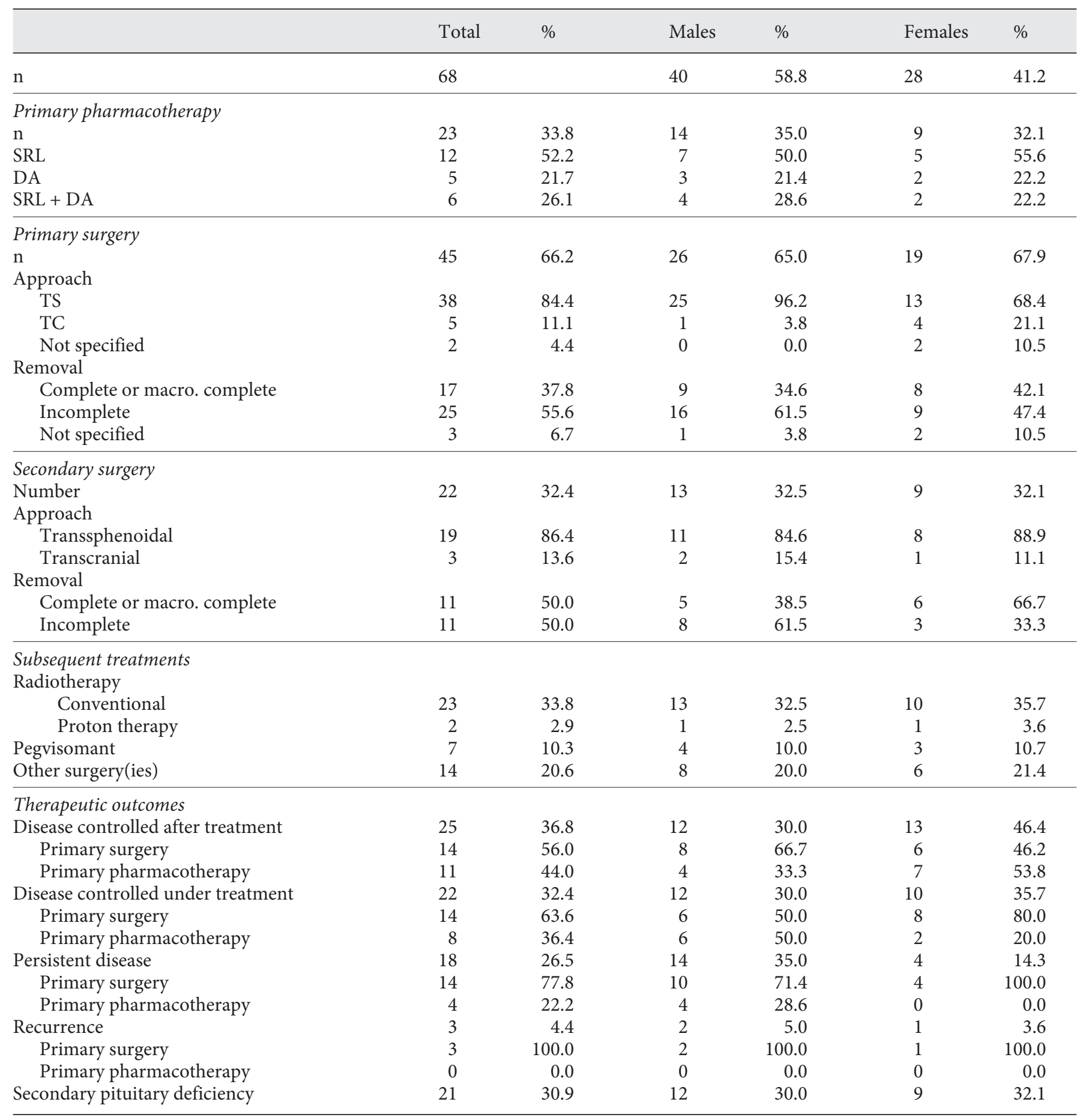

Results are from the last follow-up. SRL = Somatostatin receptor ligand; DA = dopamine agonist; macro. = macroscopically. 


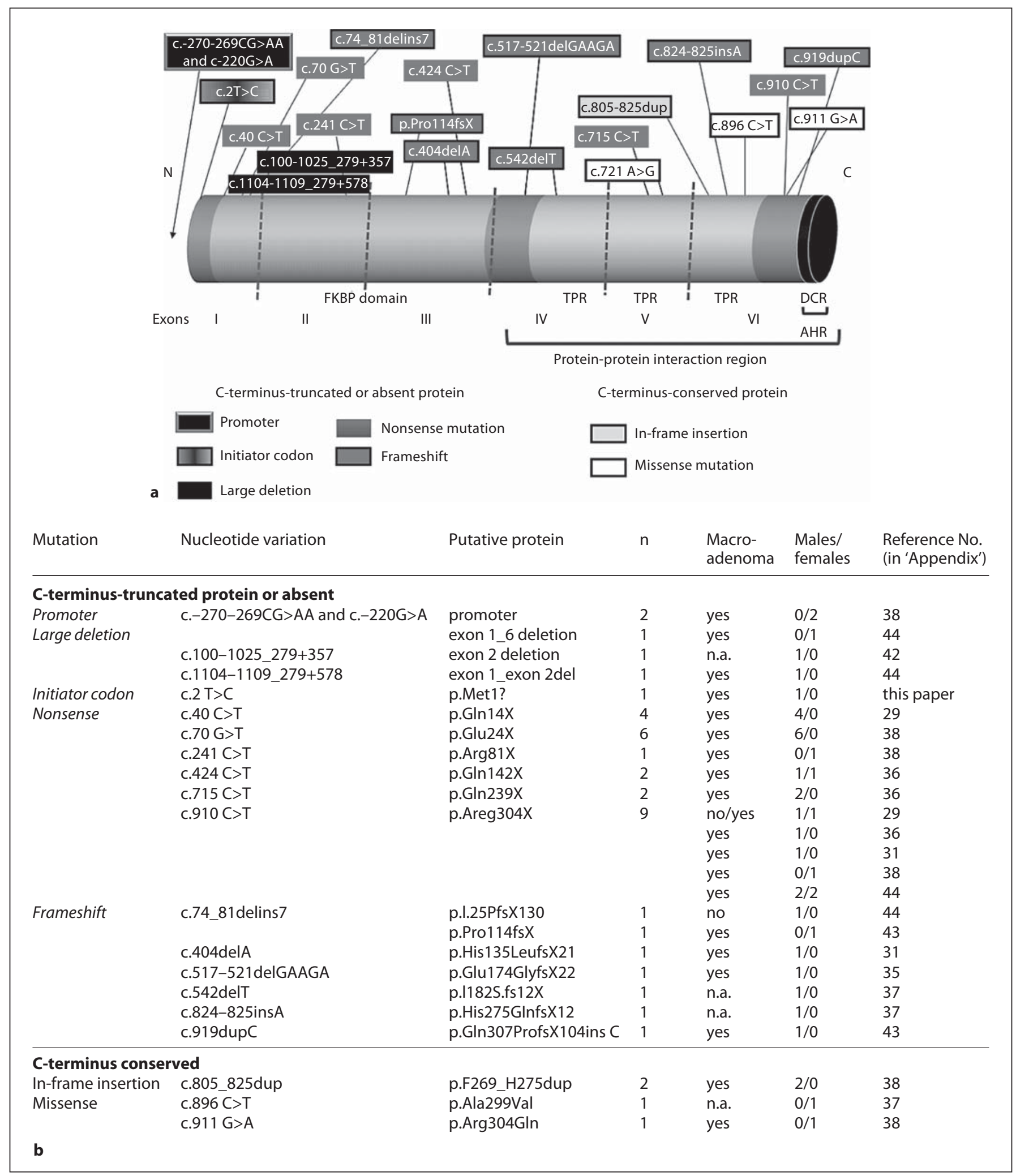

Fig. 2. Reported $A I P$ mutations in pediatric patients with acromegaly. a $A I P$ gene: the arrows indicate the positions of the mutations within the AIP gene. FKBP = FK506-binding protein; TPR = tetratricopeptide repeats; AHR = aryl hydrocarbon receptor; DCR = distal C-terminal region. b Description of AIP mutations reported in pediatric studies. 
toms. Among patients for whom relevant data were available, most had macroadenoma and frequently para- or suprasellar extension. Microadenomas were found in only $12 \%$ of patients, compared to $20-30 \%$ in adults [13].

Hyperprolactinemia is common at presentation and correlates with GH-PRL co-staining within the tumor. At diagnosis, $65 \%$ of patients in our cohort had increased prolactin levels. More than $90 \%$ of patients with high prolactin levels (nearly $50 \%$ of the entire cohort) had adenomas with double GH/PRL staining.

In our patient, peripheral blood cells were heterozygous for an AIP gene mutation (c.2T $>C$ in exon 1 ) and the tumor tissue did not contain the normal AIP allele. These genetic abnormalities were recently implicated in the pathogenesis of familial pituitary adenomas and, more rarely, of sporadic cases [14-21]. AIP mutations account for about $15 \%$ of cases of familial isolated pituitary adenomas and $50 \%$ of cases of isolated familial somatotropinomas $[15,16,22]$. These mutations are associated chiefly with GH-secreting tumors but also with prolactinomas, non-secreting adenomas, and rare cases of ACTH-secreting adenomas $[15,16,22]$. As a result of their low penetrance, germline AIP mutations are also observed in sporadic pituitary adenomas, especially in young males with invasive macroadenomas [23] (35/37 children with AIP mutations in fig. 2 had macroadenomas). Few data are available for determining the prevalence of AIP mutations in pediatric patients. However, $10-15 \%$ of acromegalic patients younger than 20 or 25 years of age may have AIP mutations [23], and the onset of somatotropinoma symptoms occurs in childhood or adolescence in about $50 \%$ of patients with AIP mutations [24]. We also noted genetic data of adults with acromegaly and AIP mutation published in the same period, to compare adult and pediatric cases. Of interest, children have significantly higher rates of mutations leading to a truncated, or probably absent, AIP protein that might explain severe phenotypes with early onset and familial involvement [90.2\% (37/41) vs. $47.0 \%$ (32/69), p < 0.001]. Moreover, somatotropinomas with AIP mutations are associated with higher $\mathrm{GH}$ levels at diagnosis and a higher prevalence of prolactin oversecretion [24]. All these characteristics complicate the treatment and reduce the probability of achieving disease control [24].

The absence of pediatric guidelines creates challenges in the treatment of children with gigantism. To date, no studies evaluating treatment strategies have been published. According to recommendations for adults [25], transsphenoidal surgery is the cornerstone of the treatment of intrasellar microadenomas and noninva- sive macroadenomas, with normal GH secretion being achieved in approximately 70 and $50 \%$ of cases, respectively [26]. In children, the small nostril diameter and incomplete sphenoid sinus pneumatization create technical challenges when performing transsphenoidal surgery, and the neurosurgeon's experience is a major predictor of success $[8,25]$. Invasive adenomas are unlikely to be controlled with surgery alone and often require multiple treatment modalities (primary pharmacotherapy or surgical debulking, postoperative medical therapy and/or radiotherapy) [25].

The best initial treatment in children is unclear. Similarly, in adults, the benefits of presurgical pharmacotherapy remain debated. Preoperative treatment with somatostatin receptor ligands improved surgical outcomes and disease control in some studies [28-30] but not in others [31,32]. Of the 68 children in this review for whom therapeutic data were available, $34 \%$ received primary pharmacological treatment and $66 \%$ immediate surgery. In patients with macroadenomas, surgical excision was complete or macroscopically complete in $55 \%$ of patients given preoperative pharmacotherapy compared to $32 \%$ of the other patients $(\mathrm{p}=0.12)$. At the last follow-up, the disease appeared controlled in $85 \%$ of patients given firstline pharmacotherapy and in 53\% of the other patients $(\mathrm{p}=0.028)$. However, follow-up duration varied across patients, and these results are insufficient to conclude that first-line pharmacotherapy is beneficial in children with macroadenomas. We are fully aware of the limitations of an analysis based on a literature review.

Three types of drugs are available for treating somatotropinoma. For adults [25], somatostatin receptor ligands are recommended as the first-line treatment when a surgical cure is unlikely to be achieved or as second-line treatment when surgery fails to achieve biochemical control. Dopamine agonists are often used as add-on therapy when a somatostatin receptor ligand in the maximal dosage fails to normalize the hormone levels. Dopamine agonists are also indicated in patients with hyperprolactinemia and/or moderately increased IGF-1 and GH levels [25]. Contrary to adult recommendations, only 14 (56\%) of the 25 patients treated with primary incomplete surgery in this review received postoperative pharmacotherapy as second-line treatment, whereas the remaining patients were treated with radiotherapy.

The third type of drug is the GH-receptor antagonist pegvisomant, which was introduced recently for the treatment of somatotropinoma in adults. Pegvisomant is used off-label in pediatric somatotropinoma. It has no effect on tumor size but normalizes IGF-1 levels in 70-97\% 
of adults after 12-14 months [9-11]. Pegvisomant is particularly valuable in patients who are unresponsive to somatostatin receptor ligands. Patients notice improvements after only a few weeks of treatment. In our review, 7 children received pegvisomant, usually as rescue therapy. Among them, 4 experienced significant clinical and biological improvements, without adverse effects $[33,34]$. One child responded inadequately to the drug [35]. The remaining 2 patients were taken off pegvisomant when they experienced tumor growth despite an initial good response (our case, [33]). This complication is infrequent $(<2 \%)$ and incompletely understood $[10,11,36]$. It may reflect not only abolition of the negative IGF-1 feedback on GH secretion but also the natural course of highly aggressive tumors [36]. Previous publications [37, 38] suggest that combining pegvisomant with a somatostatin receptor ligand may help to prevent this complication and to improve hormonal control. This combined treatment may also be helpful before surgery, with pegvisomant decreasing the IGF-1 levels and the somatostatin receptor ligand diminishing tumor volume - 2 effects associated with successful surgery $[8,27]$. In a recent pediatric case report, Bergamaschi et al. [34] suggested pegvisomant as a first-line treatment option, given the high failure rate of primary surgery. Other pediatric studies are needed to define the optimal use of this new drug. Tumor status should be carefully monitored during pegvisomant therapy.

Current recommendations indicate that radiotherapy should be used only as the last resort, usually as a thirdline treatment [25]. In our review, 25 children received radiotherapy, usually as second-line treatment (15/25). None received primary radiotherapy. In contrast to surgery and pharmacotherapy, radiotherapy has delayed effects, with several years being needed to achieve disease control $[25,39]$. Conventional fractionated radiotherapy achieves a biochemical remission in $35-75 \%$ of patients, usually after 10 years [39]. Techniques characterized by greater accuracy with less damage to healthy tissue include stereotactic radiosurgery (gamma-knife or proton therapy), which is associated with decreased radiation exposure, faster effects, and lower rates of hypopituitarism [39]. In our patient, proton therapy improved hormonal control and decreased tumor size within only 15 months. Panhypopituitarism, the main complication of radiotherapy, occurs in over $50 \%$ of patients treated with conventional fractionated radiotherapy $[10,39]$ and in $30 \%$ of those treated with radiosurgery. In our review, followups were usually too short for an accurate evaluation of radiotherapy effects, but panhypopituitarism developed in at least $28 \%$ of children given radiotherapy.
In conclusion, this large review provides a detailed picture of pediatric somatotropinoma. The vast majority of somatotropinomas in children are extensive macroadenomas. The treatment generally requires multiple modalities. Thus, surgery is combined with pharmacotherapy in many patients and with radiotherapy in some. Somatostatin receptor ligands and, less often, dopamine agonists are used for hormonal control and may shrink the tumor. GH-receptor antagonist therapy is still very rarely used but usually provides biochemical control and should be considered a first-line treatment option. Pediatric patients with pituitary adenomas should be routinely investigated for AIP mutations, which are often associated with familial forms and with large aggressive tumors.

\section{Appendix}

List of 45 Publications Used for Literature Review

1 Espiner EA, Carter TA, Abbott GD, et al: Pituitary gigantism in a 31 month old girl: endocrine studies and successful response to hypophysectomy. J Endocrinol Invest 1981;4:445450 .

2 Zampieri P, Scanarini M, Sicolo N, et al: The acromegaly-gigantism syndrome: report of four cases treated surgically. Surg Neurol 1983;20:498-503.

3 Ritzén EM, Wettrell G, Davies G, et al: Management of pituitary gigantism: the role of bromocriptine and radiotherapy. Acta Paediatr Scand 1985;74:807-814.

4 Anniko M, Ritzén EM: Pituitary tumour causing gigantism: morphology and in vitro hormone secretion. ORL J Otorhinolaryngol Relat Spec 1986;48:180-190.

5 Blumberg DL, Sklar CA, David R, et al: Acromegaly in an infant. Pediatrics 1989;83:998-1002.

6 Gelber SJ, Heffez DS, Donohoue PA: Pituitary gigantism caused by growth hormone excess from infancy. J Pediatr 1992;120:931-934.

7 Iwatani N, Kodama M, Seto H: A child with pituitary gigantism and precocious adrenarche: does GH and/or PRL advance the onset of adrenarche? Endocrinol Jpn 1992;39:251-257.

8 Lu PW, Silink M, Johnston I, et al: Pituitary gigantism. Arch Dis Child 1992;67:1039-1041.

9 Fazekas I, Pásztor E, Slowik F, et al: Pathological and experimental investigations in a case of gigantism. Acta Neuropathol 1993;85:167-174.

10 Zimmerman D, Young WF Jr, Ebersold MJ, et al: Congenital gigantism due to growth hormone-releasing hormone excess and pituitary hyperplasia with adenomatous transformation. J Clin Endocrinol Metab 1993;76:216-222.

11 Dyer EH, Civit T, Visot A, et al: Transsphenoidal surgery for pituitary adenomas in children. Neurosurgery 1994;34:207212, discussion 212.

12 Kane LA, Leinung MC, Scheithauer BW, et al: Pituitary adenomas in childhood and adolescence. J Clin Endocrinol Metab 1994;79:1135-1140. 
13 Matsuno A, Teramoto A, Yamada S, et al: Gigantism in sibling unrelated to multiple endocrine neoplasia: case report. Neurosurgery 1994;35:952-955, discussion 955-956.

14 Dubuis JM, Deal CL, Drews RT, et al: Mammosomatotroph adenoma causing gigantism in an 8-year old boy: a possible pathogenetic mechanism. Clin Endocrinol (Oxf) 1995;42: 539-549.

15 Dötsch J, Kiess W, Hänze J, et al: Gs alpha mutation at codon 201 in pituitary adenoma causing gigantism in a 6-yearold boy with McCune-Albright syndrome. J Clin Endocrinol Metab 1996;81:3839-3842.

16 Szwajkun P, Chen YR, Yeow VK, et al: The 'Taiwanese giant': hormonal and genetic influences in fibrous dysplasia. Ann Plast Surg 1998;41:75-80.

17 Alvi NS, Kirk JM: Pituitary gigantism causing diabetic ketoacidosis. J Pediatr Endocrinol Metab 1999;12:907-909.

18 Johnson MC, Codner E, Eggers M, et al: Gps mutations in Chilean patients harboring growth hormone-secreting pituitary tumors. J Pediatr Endocrinol Metab 1999;12:381-387.

19 Gadelha MR, Prezant TR, Une KN, et al: Loss of heterozygosity on chromosome 11q13 in two families with acromegaly/ gigantism is independent of mutations of the multiple endocrine neoplasia type I gene. J Clin Endocrinol Metab 1999;84: 249-256.

20 Abe T, Tara LA, Lüdecke DK: Growth hormone-secreting pituitary adenomas in childhood and adolescence: features and results of transnasal surgery. Neurosurgery 1999;45:1-10.

21 Flitsch J, Lüdecke DK, Stahnke N, et al: Transsphenoidal surgery for pituitary gigantism and galactorrhea in a 3.5 year old child. Pituitary 2000;2:261-267.

22 Maheshwari HG, Prezant TR, Herman-Bonert V, et al: Longacting peptidomimergic control of gigantism caused by pituitary acidophilic stem cell adenoma. J Clin Endocrinol Metab 2000;85:3409-3416.

23 Minagawa M, Yasuda T, Someya T, et al: Effects of octreotide infusion, surgery and estrogen on suppression of height increase and $20 \mathrm{~K}$ growth hormone ratio in a girl with gigantism due to a growth hormone-secreting macroadenoma. Horm Res 2000;53:157-160.

24 Nishio S, Morioka T, Suzuki S, et al: Pituitary tumours in adolescence: clinical behaviour and neuroimaging features of seven cases. J Clin Neurosci 2001;8:231-234.

25 Ali O, Banerjee S, Kelly DF, et al: Management of type 2 diabetes mellitus associated with pituitary gigantism. Pituitary 2007; 10:359-364.

26 De Menis E, Prezant TR: Isolated familial somatotropinomas: clinical features and analysis of the MEN1 gene. Pituitary 2002;5:11-15.

27 Luccio-Camelo DC, Une KN, Ferreira RE, et al: A meiotic recombination in a new isolated familial somatotropinoma kindred. Eur J Endocrinol 2004;150:643-648.

28 Rix M, Laurberg P, Hoejberg AS, et al: Pegvisomant therapy in pituitary gigantism: successful treatment in a 12-year-old girl. Eur J Endocrinol 2005;153:195-201.

29 Vierimaa O, Georgitsi M, Lehtonen R, et al: Pituitary adenoma predisposition caused by germline mutations in the AIP gene. Science 2006;312:1228-1230.

30 Metzler M, Luedecke DK, Saeger W, et al: Low prevalence of Gs alpha mutations in śomatotroph adenomas of children and adolescents. Cancer Genet Cytogenet 2006;166:146-151.
31 Cazabat L, Libè R, Perlemoine K, et al: Germline inactivating mutations of the aryl hydrocarbon receptor-interacting protein gene in a large cohort of sporadic acromegaly: mutations are found in a subset of young patients with macroadenomas. Eur J Endocrinol 2007;157:1-8.

32 Colao A, Pivonello R, Di Somma C, et al: Growth hormone excess with onset in adolescence: clinical appearance and long-term treatment outcome. Clin Endocrinol (Oxf) 2007;66: 714-722.

33 Ali O, Banerjee S, Kelly DF, et al: Management of type 2 diabetes mellitus associated with pituitary gigantism. Pituitary 2007;10:359-364.

34 Bowden SA, Sotos JF, Stratakis CA, et al: Successful treatment of an invasive growth hormone-secreting pituitary macroadenoma in an 8-year-old boy. J Pediatr Endocrinol Metab 2007; 20:643-647.

35 Naves LA, Daly AF, Vanbellinghen JF, et al: Variable pathological and clinical features of a large Brazilian family harbouring a mutation in the aryl hydrocarbon receptor-interacting protein gene. Eur J Endocrinol 2007;157:383-391.

36 Daly AF, Vanbellinghen JF, Khoo SK, et al: Aryl hydrocarbon receptor-interacting protein gene mutations in familial isolated pituitary adenomas: analysis in 73 families. J Clin Endocrinol Metab 2007;92:1891-1896.

37 Georgitsi M, Raitila A, Karhu A, et al: Molecular diagnosis of pituitary adenoma predisposition caused by aryl hydrocarbon receptor-interacting protein gene mutations. Proc Natl Acad Sci USA 2007; 104:4101-4105.

38 Leontiou CA, Gueorguiev M, van der Spuy J, et al: The role of the aryl hydrocarbon receptor-interacting protein gene in familial and sporadic pituitary adenomas. J Clin Endocrinol Metab 2008;93:2390-2401.

39 Tajima T, Tsubaki J, Ishizu K, et al: Case study of a 15-year-old boy with McCune-Albright syndrome combined with pituitary gigantism: effect of octreotide-long acting release (LAR) and cabergoline therapy. Endocr J 2008;55:595-599.

40 Narayanaswamy V, Rettig KR, Bhowmick SK: Excessive growth. Clin Pediatr (Phila) 2008;47:705-708.

41 Goldenberg N, Racine MS, Thomas P, et al: Treatment of pituitary gigantism with the growth hormone receptor antagonist pegvisomant. J Clin Endocrinol Metab 2008;93:2953-2956.

42 Georgitsi M, Heliövaara E, Paschke R, Kumar AV, Tischkowitz M, Vierimaa O, Salmela P, Sane T, De Menis E, Cannavò S, Gündogdu S, Lucassen A, Izatt L, Aylwin S, Bano G, Hodgson S, Koch CA, Karhu A, Aaltonen LA: Large genomic deletions in AIP in pituitary adenoma predisposition. J Clin Endocrinol Metab 2008;93:4146-4151.

43 Stratakis CA, Tichomirowa MA, Boikos S, et al: The role of germline AIP, MEN1, PRKAR1A, CDKN1B and CDKN2C mutations in causing pituitary adenomas in a large cohort of children, adolescents, and patients with genetic syndromes. Clin Genet 2010;78:457-463.

44 Igreja S, Chahal HS, King P, et al: Characterization of aryl hydrocarbon receptor interacting protein (AIP) mutations in familial isolated pituitary adenoma families. Hum Mutat 2010; 31:950-960.

45 Bergamaschi S, Ronchi CL, Giavoli C, et al: Eight-year followup of a child with a $\mathrm{GH} /$ prolactin-secreting adenoma: efficacy of pegvisomant therapy. Horm Res Paediatr 2010;73:7479. 


\section{Acknowledgments}

The authors gratefully acknowledge the help received from Marie Laure Raffin-Sanson MD, PhD (Functional Unit of Endocrinology and Diabetology, Ambroise Paré Hospital, BoulogneBillancourt) for her contribution to this study and Caroline Elie MD (Unit of Biostatistics, Necker-Enfants Malades Hospital, Paris) for her contribution to the statistical analysis. We also thank Bertrand Chevalier MD, PhD (Pediatric Unit, Ambroise Paré Hospital, Boulogne-Billancourt) for referring the patient and Zeina Ajaltouni MD, for her help with the care of the patient.

The clinical case was presented in abstract form at the 2008 meeting of the European Society of Paediatric Endocrinology.

\section{Disclosure Statement}

The authors have no conflicts of interest to disclose. This research did not receive a grant from any funding agency in the public, commercial or not-for-profit sectors.

\section{References}

$\checkmark 1$ Lafferty AR, Chrousos GP: Pituitary tumors in children and adolescents. J Clin Endocrinol Metab 1999;84:4317-4323.

-2 Jagannathan J, Dumont AS, Jane JA Jr, Laws ER Jr: Pediatric sellar tumors: diagnostic procedures and management. Neurosurg Focus 2005;18:E6.

$\checkmark 3$ Horvath A, Stratakis CA: Clinical and molecular genetics of acromegaly: MEN1, Carney complex, McCune-Albright syndrome, familial acromegaly and genetic defects in sporadic tumors. Rev Endocr Metab Disord 2008;9:1-11.

4 Beckers A, Daly AF: The clinical, pathological, and genetic features of familial isolated pituitary adenomas. Eur J Endocrinol 2007; 157:371-382.

$\checkmark 5$ Daly AF, Beckers A: Update on the treatment of pituitary adenomas: familial and genetic considerations. Acta Clin Belg. 2008;63:418424

-6 Mehrazin M: Pituitary tumors in children: clinical analysis of 21 cases. Childs Nerv Syst 2007;23:391-398.

7 Abe T, Tara LA, Lüdecke DK: Growth hormone-secreting pituitary adenomas in childhood and adolescence: features and results of transnasal surgery. Neurosurgery 1999;45:1-10.

$>8$ Dyer EH, Civit T, Visot A, Delalande O, Derome P: Transsphenoidal surgery for pituitary adenomas in children. Neurosurgery 1994;34:207-212.

9 Trainer PJ, Drake WM, Katznelson L, et al: Treatment of acromegaly with the growth hormone-receptor antagonist pegvisomant. N Engl J Med 2000;342:1171-1177.

$\checkmark 10$ Colao A, Attanasio R, Pivonello R, Cappabianca P, Cavallo LM, Lasio G, Lodrini A, Lombardi G, Cozzi R: Partial surgical removal of growth hormone-secreting pituitary tumors enhances the response to somatostatin analogs in acromegaly. J Clin Endocrinol Metab 2006;91:85-92.
11 Van der Lely AJ, Hutson RK, Trainer PJ, et al: Long-term treatment of acromegaly with pegvisomant, a growth hormone receptor antagonist. Lancet 2001;358:1754-1759.

12 Blumberg DL, Sklar CA, David R, Rothenberg S, Bell J: Acromegaly in an infant. Pediatrics 1989;83:998-1002.

13 Bowden SA, Sotos JF, Stratakis CA, Weil RJ: Successful treatment of an invasive growth hormone-secreting pituitary macroadenoma in an 8-year-old boy. J Pediatr Endocrinol Metab 2007;20:643-647.

- 14 Vierimaa O, Georgitsi M, Lehtonen R, Vahteristo P, Kokko A, Raitila A, Tuppurainen K, Ebeling TM, Salmela PI, Paschke R, Gundogdu S, De Menis E, Makinen MJ, Launonen V, Karhu A, Aaltonen LA: Pituitary adenoma predisposition caused by germline mutations in the AIP gene. Science 2006;312: 1228-1230.

15 Daly AF, Vanbellinghen JF, Khoo SK, Jaffrain-Rea ML, Naves LA, Guitelman MA, Murat A, Emy P, Gimenez-Roqueplo AP, Tamburrano G, Raverot G, Barlier A, De Herder W, Penfornis A, Ciccarelli E, Estour B, Lecomte P, Gatta B, Chabre O, Sabate MI, Bertagna X, Garcia Basavilbaso N, Stalldecker G, Colao A, Ferolla P, Wemeau JL, Caron P, Sadoul JL, Oneto A, Archambeaud F, Calender A, Sinilnikova O, Montanana CF, Cavagnini F, Hana V, Solano A, Delettieres D, Luccio-Camelo DC, Basso A, Rohmer V, Brue T, Bours V, Teh BT, Beckers A: Aryl hydrocarbon receptor-interacting protein gene mutations in familial isolated pituitary adenomas: analysis in 73 families. J Clin Endocrinol Metab 2007;92:1891-1896.

16 Georgitsi M, Raitila A, Karhu A, Tuppurainen K, Makinen MJ, Vierimaa O, Paschke R, Saeger W, van der Luijt RB, Sane T, Robledo M, De Menis E, Weil RJ, Wasik A, Zielinski G, Lucewicz O, Lubinski J, Launonen V, Vahteristo P, Aaltonen LA: Molecular diagnosis of pituitary adenoma predisposition caused by aryl hydrocarbon receptor-interacting protein gene mutations. Proc Natl Acad Sci USA 2007;104:4101-4105.
17 Iwata T, Yamada S, Mizusawa N, Golam HM, Sano T, Yoshimoto K: The aryl hydrocarbon receptor-interacting protein gene is rarely mutated in sporadic GH-secreting adenomas. Clin Endocrinol (Oxf) 2007;66:499502

18 Toledo RA, Lourenço DM Jr, Liberman B, Cunha-Neto MB, Cavalcanti MG, Moyses CB, Toledo SP, Dahia PL: Germline mutation in the aryl hydrocarbon receptor interacting protein gene in familial somatotropinoma. J Clin Endocrinol Metab 2007;92:1934-1937.

19 Leontiou CA, Gueorguiev M, van der Spuy J, Quinton R, Lolli F, Hassan S, Chahal HS, Igreja SC, Jordan S, Rowe J, Stolbrink M, Christian HC, Wray J, Bishop-Bailey D, Berney DM, Wass JA, Popovic V, RibeiroOliveira A Jr, Gadelha MR, Monson JP, Akker SA, Davis JR, Clayton RN, Yoshimoto K, Iwata T, Matsuno A, Eguchi K, Musat M, Flanagan D, Peters G, Bolger GB, Chapple JP, Frohman LA, Grossman AB, Korbonits M: The role of the aryl hydrocarbon receptorinteracting protein gene in familial and sporadic pituitary adenomas. J Clin Endocrinol Metab 2008;93:2390-2401.

20 Igreja S, Chahal HS, King P, Bolger GB, Srirangalingam U, Guasti L, Chapple JP, Trivellin G, Gueorguiev M, Guegan K, Stals K, Khoo B, Kumar AV, Ellard S, Grossman AB, Korbonits M: International FIPA Consortium. Characterization of aryl hydrocarbon receptor interacting protein (AIP) mutations in familial isolated pituitary adenoma families. Hum Mutat 2010;31:950-960.

21 Chahal HS, Stals K, Unterländer M, Balding DJ, Thomas MG, Kumar AV, Besser GM, Atkinson AB, Morrison PJ, Howlett TA, Levy MJ, Orme SM, Akker SA, Abel RL, Grossman AB, Burger J, Ellard S, Korbonits M: AIP mutation in pituitary adenomas in the 18 th century and today. N Engl J Med 2011; $364: 43-50$ 
-22 Stratakis CA, Tichomirowa MA, Boikos S, Azevedo MF, Lodish M, Martari M, Verma S, Daly AF, Raygada M, Keil MF, Papademetriou J, Drori-Herishanu L, Horvath A, Tsang KM, Nesterova M, Franklin S, Vanbellinghen JF, Bours V, Salvatori R, Beckers A: The role of germline AIP, MEN1, PRKA$\mathrm{R} 1 \mathrm{~A}, \mathrm{CDKN} 1 \mathrm{~B}$ and CDKN2C mutations in causing pituitary adenomas in a large cohort of children, adolescents, and patients with genetic syndromes. Clin Genet 2010;78:457463.

23 Cazabat L, Guillaud-Bataille M, Bertherat J, Raffin-Sanson ML: Mutations of the gene for the aryl hydrocarbon receptor-interacting protein in pituitary adenomas. Horm Res 2009;71:132-141.

24 Daly AF, Tichomirowa MA, Petrossians P, Heliövaara E, Jaffrain-Rea ML, Barlier A, Naves LA, Ebeling T, Karhu A, Raappana A, Cazabat L, De Menis E, Montañana CF, Raverot G, Weil RJ, Sane T, Maiter D, Neggers S, Yaneva M, Tabarin A, Verrua E, Eloranta E, Murat A, Vierimaa O, Salmela PI, Emy P, Toledo RA, Sabaté MI, Villa C, Popelier M, Salvatori R, Jennings J, Longás AF, Labarta Aizpún JI, Georgitsi M, Paschke R, Ronchi C, Valimaki M, Saloranta C, De Herder W, Cozzi R, Guitelman M, Magri F, Lagonigro MS, Halaby G, Corman V, Hagelstein MT, Vanbellinghen JF, Barra GB, Gimenez-Roqueplo AP, Cameron FJ, BorsonChazot F, Holdaway I, Toledo SP, Stalla GK, Spada A, Zacharieva S, Bertherat J, Brue T, Bours V, Chanson P, Aaltonen LA, Beckers A: Clinical characteristics and therapeutic responses in patients with germ-line AIP mutations and pituitary adenomas: an international collaborative study. J Clin Endocrinol Metab 2010;95:E373-E383.
25 Melmed S, Colao A, Barkan A, Molitch M, Grossman AB, Kleinberg D, Clemmons D, Chanson P, Laws E, Schlechte J, Vance ML, Ho K, Giustina A: Guidelines for acromegaly management: an update. Acromegaly Consensus Group. J Clin Endocrinol Metab 2009;94:1509-1517.

26 Laws ER: Surgery for acromegaly: evolution of the techniques and outcomes. Rev Endocr Metab Disord 2008;9:67-70.

27 Lüdecke DK, Herrmann HD, Schulte FJ: Special problems with neurosurgical treatment of hormone-secreting pituitary adenomas in children. Prog Exp Tumor Res 1987;30:362370.

28 Mao ZG, Zhu YH, Tang HL, Wang DY, Zhou J, He DS, Lan H, Luo BN, Wang HJ: Preoperative lanreotide treatment in acromegal ic patients with macroadenomas increases short-term postoperative cure rates: a prospective, randomised trial. Eur J Endocrinol 2010;162:661-666.

29 Colao A, Ferone D, Cappabianca P, del Basso De Caro ML, Marzullo P, Monticelli A, Alfieri A, Merola B, Cali A, de Divitiis E, Lombardi G: Effect of octreotide pretreatment on surgical outcome in acromegaly. J Clin Endocrinol Metab 1997;82:3308-3314.

30 Abe T, Ludecke DK: Effects of preoperative octreotide treatment on different subtypes of $90 \mathrm{GH}$-secreting pituitary adenomas and outcome in one surgical centre. Eur J Endocrinol 2001;145:137-145.

31 Losa M, Mortini P, Urbaz L, Ribotto P, Castrignano T, Giovanelli M: Presurgical treatment with somatostatin analogs in patients with acromegaly: effects on the remission and complication rates. J Neurosurg 2006; 104:899-906.
Plockinger U, Quabbe HJ: Presurgical octreotide treatment in acromegaly: no improvement of final growth hormone $(\mathrm{GH})$ concentration and pituitary function: a longterm case-control study. Acta Neurochir (Wien) 2005; 147:485-493

- 33 Goldenberg N, Racine MS, Thomas P, Degnan B, Chandler W, Barkan A: Treatment of pituitary gigantism with the growth hormone receptor antagonist pegvisomant. J Clin Endocrinol Metab 2008;93:2953-2956.

34 Bergamaschi S, Ronchi CL, Giavoli C, Ferrante E, Verrua E, Ferrari DI, Lania A, Rusconi R, Spada A, Beck-Peccoz P: Eight-year follow-up of a child with a $\mathrm{GH} /$ prolactin-secreting adenoma: efficacy of pegvisomant therapy. Horm Res Paediatr 2010;73:74-79.

35 Ali O, Banerjee S, Kelly DF, Lee PD: Management of type 2 diabetes mellitus associated with pituitary gigantism. Pituitary 2007;10: 359-364.

- 36 Frohman LA, Bonert V: Pituitary tumor enlargement in two patients with acromegaly during pegvisomant therapy. Pituitary 2007 ; 10:283-289.

37 Jorgensen JO, Feldt-Rasmussen U, Frystyk J, Chen JW, Kristensen LO, Hagen C, Orskov $\mathrm{H}$ : Cotreatment of acromegaly with a somatostatin analog and a growth hormone receptor antagonist. J Clin Endocrinol Metab 2005;90:5627-5631.

38 Neggers SJ, van Aken MO, Janssen JA, Feelders RA, de Herder WW, van der Lely AJ: Long-term efficacy and safety of combined treatment of somatostatin analogs and pegvisomant in acromegaly. J Clin Endocrinol Metab 2007;92:4598-4601.

39 Rowland NC, Aghi MK: Radiation treatment strategies for acromegaly. Neurosurg Focus 2010;29:E12. 